\title{
Leadership Style of Principal to Increase Teacher's Professionality
}

\author{
Liyal Khaira* \\ Magister of Educational Administration \\ Syiah Kuala University \\ Banda Aceh, Indonesia \\ *liyalkhaira@gmail.com
}

\author{
Murniati A.R., Nasir Usman \\ School of Educational \\ Syiah Kuala University \\ Banda Aceh, Indonesia \\ murniati@unsyiah.ac.id,nasir@unsyiah.ac.id
}

\begin{abstract}
Goal of this research is to examine the leadership style of the principal in improving the professional competence of MI teachers in UPTD East Peurelak region, East Aceh Regency. This study applied a qualitative descriptive method. The subject of this study was determined by using purposive sampling. It included fifteen informants for completing this research. In order to collect data, researcher conducted interviews, observation, and documentation. The result showed: 1) principal applied situational leadership method, indicator acts as telling the division of assignment based on academic qualification, participating teachers in discussion forum, selling to give reward for the competent teachers, delegating to make decision for importance in the school; 2) principal acts to give chance for teachers for self-development by attending a training, seminar, KKG, permitting for continuing study; 3) as a strategy, principal oblige teachers to attend a computer course and supervision program, to evaluate students' learning outcomes, and take part in training of usage in online report submission; 4) while, the principal faces some obstacles to apply this method, such as, teachers' difficulty to communicate, lack of IT mastery, deficiency of teachers' awareness to make an effective learning environment.
\end{abstract}

\section{Keywords-leadership style, principal, professional competency}

\section{INTRODUCTION}

The era of globalization is an era development that relates to the development of technology-based science in improving self-quality, competent human resources, mastering science and technology, and having strong integrity. Education plays an important role in determining the quality of Human Resources (HR) who will create potential generations and skills through planned and systematic education. According to Mulyasa education provides flexibility to schools in developing various potentials that require increasing the ability of school principals in various managerial aspects in order to achieve goals in accordance with the vision and mission of the school [1].

The school principal as a leader as well as teachers and staff as employees who are partly responsible for the success of the school. Schools as educational institutions that are able to improve the quality of human resources in quality improvement, need to be managed, regulated, organized and empowered, in order to produce quality products. Internally, the school components, namely teachers, students, curriculum, facilities and infrastructure. While externally, schools have and are associated with other agencies both vertically and horizontally. Leadership is defined as the process of influencing the activities of a person or group to achieve goals in certain situations [2].

Regulation of the Minister of National Education Number 16 of 2007 concerning academic qualification standards and teacher competence states that teacher competency standards are pedagogical competence, personal competence, and professional competence and social competence. A teacher must master the field of science and technology and the field under which he / she covers at least the following mastery of: 1) subject matter broadly and mastering the standard content of the educational unit program; 2) Concepts and methods of scientific discipline, relevant technology that is conceptually related to the educational unit program, subjects or groups of subjects to be taught. The principal as a leader who influences teachers in increasing competence and carrying out duties with full responsibility according to procedures. The success of teacher performance is influenced by several factors, namely work motivation, work ethic, work environment, duties and responsibilities, optimization at work [3]. The success of the school will depend on how the motivation, environment and duties are assigned to its members in carrying out their duties. So, a leader who has a high vision and mission is required to influence people to follow his direction.

Leadership style is a behavior that is inherent in a person to influence others in organizations so that people move and carry out their duties and imitate their personal attitudes and characteristics in achieving goals. Leadership style is the attitude, behavior and actions as well as methods of managing Human Resources (HR) around the environment to achieve the planned vision with the cooperation of the entire team [4]. The ability and behavior of school principals are able to influence teachers to carry out their duties professionally and have high motivation. The principal is the most important person who provides work motivation to teachers, staff, stakeholders and schoolin achieving the success of national education goals [5] 
Therefore, researchers are interested in examining how the principal's leadership style is in improving the professional competence of Madrasah teachers in the location of the Technical Implementation Unit of the Peureulak Timur Office, East Aceh Regency.

\section{RESEARCH METHODS}

The research subjects will be determined based on purposive sampling, the informants in this study were 15 (fifteen) respondents, data collection was obtained from interviews, observation, and documentation study. Before the questionnaire was used in this study, a trial was conducted to determine the validity and reliability of the instrument. These results are used as an instrument to collect data in field research. Data analysis techniques include 1) data reduction, 2) data display (data presentation), 3) drawing conclusions or verification. The procedures for collecting qualitative research data are interviews, observation, documentation. The path of data analysis is data reduction, data presentation and conclusion drawing.

\section{RESULTS AND DISCUSSION}

A. The Leadership style of the Principal in Improving the Professional Competence of Madrasah Ibtidaiyah

Teachers in the Regional Technical Implementation Unit of the East Aceh District Peureulak Office

Based on the results of research on three Madrasah Ibtidaiyah (MI) Regional Technical Implementation Units of the East Peureulak Service, namely MIN 13 East Aceh, MIN 32 East Aceh, MIS Kruet Lintang, in improving the professional competence of madrasah ibtidaiyah teachers. The principal applies several leadership styles including participatory style, visionary style, instructive style, authoritarian style, delegative style and transactional style. Leadership is a pattern of relationships between individuals who use authority and influence on another person or group of people to form cooperation to complete a task [6]. Participatory leadership relates to using decision procedures that affect others which refer to aspects of consultation, joint decision making, power sharing, decentralization and democracy [7].

Furthermore, Hersey and Blanchard explain that the situational leadership style is grouped into four parts, namely the style of telling, selling, participacing and delegating, judging by the employee's condition of readiness and willingness. encourage teachers to complete their duties according to the implementation in school [8].

The leadership style of the principal will apply various conditions in every decision making to achieve the expected success. There are three different types of leadership styles, namely autocratic, democratic or participatory and laissez faire, all of which must have weaknesses and strengths [2]. Based on this opinion, the application of a participatory style provides opportunities for teachers to speak, argue, provide suggestions, and find solutions to problems or difficulties faced in decision making to good interpersonal relationships in finding solutions to problems.

The ability of principals and teachers to control and get used to not taking actions that violate applicable rules as a form of responsibility for tasks that have been given to carry out according to the rules and not in conflict with something that has been set in a school or an institution Furthermore, in line with opinion Danim's Competence is part of knowledge, skills and specific values in a person in training habits of thinking and acting logically [9]. According to Rofa'ah, competence is a skill or ability, competence comes from English, namely competence which means knowledge, skills, and abilities [10]. In line with Supardi states that: "Teachers who are aware of their responsibilities are teachers who know, understand and act according to applicable norms" [11]. Competence related to the way of thinking and knowledge of a person who does work as a profession.

Knowledge is something that is obtained from reading and experience, while knowledge is knowledge obtained by walking information [3]. In line with according to Amran, in developing professional is needed; knowledge; ability; Skills; self-attitude; and habits. Professional educators must be skilled, bring themselves by example to others and habits that are carried out are able to influence the environment and students [3].

B. The Role of the Principal in Running Programs in Schools is to Improve the Professional Competence of Madrasah Ibtidaiyah Teachers in the Regional Technical Implementation Unit of the Peureulak Timur Office, East Aceh Regency.

The principal is an important part of the school, which is responsible for and carries out managerial functions, planning functions, supervisory functions, support functions andfunctions social among stakeholders in the school environment. Many factors influence the success of a leader in managing an organization, including [12]: (a) intellect, (b) social relationships, (c) emotional ability, (d) physical condition, (e) imagination, (f) physical strength, (g) patience, (h) willingness to sacrifice, and (i) willingness to work hard.

In connection with the above, the principal is basically an educator who fosters teachers and explores the ability of teachers to develop and improve. The philosophy of school principal educators is that first, school principals play an important role in improving the quality of education [5]. The two school principals always improve their dedication and creativity in carrying out their duties in a professional manner. The principal as a leader who will influence the improvement of teacher professional performance and discipline to achieve national education goals. The leadership performance of school principals is able to improve the quality of teacher teaching, school facilities, school programs and services aimed at ensuring the quality of quality learning services [13].

In this case, the principal must improve the professional competence of teachers in the success of a quality learning 
process and the formulation of school programs that support the abilities of teachers and students. The professional ability of teachers is the ability to carry out teaching assignments obtained through education, namely the teacher's academic background and the teacher's experience obtained in his education [14]. The ability of the principal is an influence on teacher performance which has an impact on the success of the progress of teacher competence to carry out responsible tasks. Performance is the result of work both in quality and quantity achieved by a person in carrying out tasks according to given responsibilities [15]. Performance as the performance of a person's work carrying out duties and responsibilities that are given to him according to his function and position [16]. Performance is the result of hard work and part of the responsibility given according to the trust that has been assigned.

The principal involves teachers, staff and students to create mutually beneficial cooperative relationships in the form of a comfortable learning process, skilled teachers, improving welfare and giving rewards to teachers in order to create a conducive atmosphere by studying the abilities of employees.

\section{The Principal's Strategy in Improving the Professional Competence of Madrasah Ibtidaiyah Teachers in the Regional Technical Implementation Unit of the East Aceh District Office of Peureulak}

The principal in carrying out the socialization of the vision, mission and goals of the school is carried out with various kinds of activities. The main function of leaders in improving quality is to empower teachers and give them broad authority to improve student learning [17]. Mulyasa explains that [16]: 1) interesting activities to maximize performance; 2) Description clearly to the employee; 3) Inform employee performance; 4) Provide rewards and punishments for violators; 5) Fulfilling the needs of employees in the form of security and good communication.

Implementation of enhancing the professional competence of teachers by the principal of training for the preparation of syllabus and lesson plans, participating in teacher group work, participating in trainings and upgrades both at school and outside of school and increasing the development of teacher academic qualifications to a higher level. Education policy is a formulation of all means to achieve the goals of national education [5]. Framework for strategic planning activities based on the formulation of vision, mission and values, examining the strategic environment, strategic analysis, and keys to success, setting goals, objectives and organizational strategy [13].

\section{Obstacles Faced by School Principals in Improving the Professional Competence of Madrasah Ibtidaiyah Teachers in the Regional Technical Implementation Unit of the East Aceh District Peureulak Office.}

The obstacles faced by the principal are a challenge in the world of schools, and educational institutions, especially schools. Some of the obstacles that are often found in schools are a school environment that is not conducive, the ability of teachers is less than optimal in carrying out their duties, the personality of the teacher who is still lacking in responsibility and the motivation of teachers in learning the use of technology is still not good at IT. Motivation is the creation of encouragement to achieve certain goals [18]. The greater the interest in a person's motivation, the more performance is created, but on the contrary, the less motivation in a person, the less optimal performance or the impression that he is only doing a task

The importance of work motivation that will influence, channel, and support human behavior to work more actively and enthusiastically to achieve optimal results [19]. Supardi states that: "Teachers who are aware of their responsibilities are teachers who know, understand and act according to applicable norms" [11]. Motivation is an encouragement to do work optimally with full responsibility for the given task. Another obstacle faced by the principal is the lack of discipline of teachers in class management that only fulfills their duties as teachers. In line with Sumardi, professional competence is to master the scientific substance of understanding teaching material in the school curriculum, school structure, concepts and methods, applying the knowledge in everyday life; mastering research and critical steps in deepening the science or field that is effective [20].

The basic discipline is the ability to get used to not taking actions that are not in accordance with applicable rules [21]. Furthermore, Hasibuan explains the indicators that can affect the level of discipline [22], namely (1) the goals and abilities of employees; (2) leaders become role models; (3) remuneration; (4) justice; (5) referee; (6) penal sanctions; (7) assertiveness; (8) penalties. Discipline and several influencing factors can increase teacher commitment in carrying out tasks in a professional manner.

The existence of the principal as a manager has a specific role in developing and empowering various resources in achieving maximum learning outcomes, the principal's hard work motivates teachers to carry out activities to improve professional competence, and the expected success of teaching and learning under current conditions.

\section{CONCLUSION}

The principal applies a situational leadership style by increasing the ability of the teacher in terms of telling, namely informing the teacher's assignments, passively by providing opportunities in discussion forums, instructing teachers in dealing with any problems by finding solutions, the principal delegates authority to the teacher under strict supervision. The role that the principal has as an educator is as an example for teachers, being a supervisor in supervising and observing every activity carried out, managing or as a manager in schools to assign appropriate assignments to teachers, forming work teams to create a culture of mutual respect and a work climate conducive, the principal creates a work program according to 
the rules applicable in the school. The principal supervises and guides teachers in improving their abilities through supervisory programs, evaluating learning outcomes, requiring teachers to use technology, namely filling out online report cards. Some teachers find it difficult to communicate with leaders, the ability of teachers to use technology is not optimal, classroom management is less innovative, the covid period of teachers and students learning are ineffective and efficient due to distance and technological tools that students do not have.

\section{REFERENCES}

[1] S. Suroso, R. Rusdarti, and C.B. Utomo, "Pengaruh Supervisi Akademik, Pendidikan Dan Pelatihan, Kompetensi Profesional Guru Terhadap Kinerja Guru Melalui Motivasi Kerja Sebagai Variabel Intervening," Educ. Manag., vol. 4, no. 2, 2015.

[2] W.G. Supartha and D.K. Sintaasih, Pengantar Perilaku Organisasi (Teori, Kasus, dan Aplikasi Penelitian). Bali: CV. Setia Bakti, 2017.

[3] D. Pianda, Kinerja guru: kompetensi guru, motivasi kerja dan kepemimpinan kepala sekolah. CV Jejak (Jejak Publisher), 2018.

[4] B. Siallagan, Leaders Guide to having Leadership. Surabaya: CV. Garuda Mas Sejahtera, 2015.

[5] H. Fajri and A.R. Murniati, "Strategi Kepala Sekolah Dalam Meningkatkan Disiplin Dan Motivasi Kerja Guru SD Negeri 36 Laksana Banda Aceh," Jurnal Administrasi Pendidikan: Program Pascasarjana Unsyiah, vol. 2, no. 2, 2014

[6] D.N. Anggarini, "Kontribusi Kepemimpinan Kepala Sekolah, Budaya Organisasi dan Implementasi Manajemen Berbasis Sekolah terhadap Mutu SMP Negeri di Kabupaten Pemalang," Educational Management, vol. 3, no. 1, 2014.

[7] A. Lestari, "Pengaruh kepemimpinan partisipatif dan komitmen organisasi terhadap efektifitas implementasi rencana stratejik pada madrasah aliyah di kabupaten sukabumi jawa barat," Jurnal Administrasi Pendidikan, vol. 23, no. 1, 2016

[8] F. Limantara, "Gaya Kepemimpinan Situasional Pada CV. Sumber Makmur,” Agora, vol. 4, pp. 27-32, 2016.

[9] A. Nirwana and A.R. Murniati, "Strategi Kepala Sekolah Dalam Meningkatkan Kompetensi Profesional Guru Pada SD Negeri 2 Kota Banda Aceh,” J. Adm. Pendidik. Progr. Pascasarj. Unsyiah, vol. 3, no. 4, 2015.

[10] R.A. Rofa'ah, Pentingnya Kompetensi Guru dalam Kegiatan Pembelajaran dalam Perspektif Islam. Yogyakarta: Deepublish, 2016.
[11] S. Nurbaya and D. Harun, "Gaya Kepemimpinan Kepala Sekolah Dalam Meningkatkan Kinerja Guru Pada SD Negeri Lambaro Angan,” Jurnal Administrasi Pendidikan Pascasarjana, vol 3, no. 2, pp. 116-127, 2015.

[12] N. Librianty, "Strategi Kepala Sekolah Dalam Meningkatkan Profesionalisme Guru di SD Muhamadiyah Kota Bangkinang," J. Basicedu, vol. 2, no. 2, pp. 1-4, 2018.

[13] S. Wiliandini, Y.S. Mulyati, and C. Triatna, "Studi Kasus Perencanaan Strategik Madrasah Tsanawiyah Yang Berorientasi Terhadap Peningkatan Mutu Layanan Pembelajaran Keagamaan," Jurnal Administrasi Pendidikan, vol. 23, no. 1, 2016.

[14] M. Syukurdi, N. Usman, and C.Z. Harun, "Kompetensi Kepalasekolah Sebagai Supervisor Dalam Pembinaan Profesionalisme Guru Di SMA Negeri 1 Peukan Bada Kabupaten Aceh Besar." Jurnal Administrasi Pendidikan: Program Pascasarjana Unsyiah, vol. 3 no. 2, 2015.

[15] D.A. Utama and R. Setiyani, "Pengaruh Transparansi, Akuntabilitas, Dan Responsibilitas Pengelolaan Keuangan Sekolah Terhadap Kinerja Guru," Dinamika Pendidikan, vol. 9, no. 2, 2014.

[16] M. Mukhtar, "Strategi kepala sekolah dalam meningkatkan kinerja guru pada SMP Negeri di Kecamatan Masjid Raya Kabupaten Aceh Besar," Jurnal Administrasi Pendidikan Program Pascasarjana Unsyiah, vol. 3, no. 3, pp. 93917, 2015.

[17] N. Nurasiah, A.R. Murniati, and C.Z. Harun, "Strategi Kepala Sekolah dalam Peningkatan Mutu di SD Negeri 1 Peukan Bada Aceh Besar,” J. Adm. Pendidik. Progr. Pascasarj. Unsyiah, vol. 3, no. 3, p. 94681, 2015.

[18] R.S. Dewi, "Kemampuan Profesional Guru Dan Motivasi Kerja Terhadap Kinerja Mengajar Guru Sekolah Dasar," Jurnal Administrasi Pendidikan, vol. 25, pp. 150-159, 2018.

[19] I. Sari and N. Nurdin, "Pengaruh Komunikasi Internal Terhadap Motivasi Kerja Pegawai,” Jurnal Administrasi Pendidikan, vol. 23, no. 1, 2016

[20] S. Sumardi, Pengembangan Profesionalisme Guru Berbasis MGMP: Model dan Implementasinya Untuk Meningkatkan Kinerja Guru. Yogyakarta: Deepublish, 2016.

[21] Y. Erwan, "Gaya Kepemimpinan Kepala Sekolah Dalam Meningkatkan Kinerja Guru Di Gugus Vii Kecamatan Sultan Daulat Kota Subulussalam," Jurnal Administrasi Pendidikan: Program Pascasarjana Unsyiah, vol. 6, no. 1, 2018.

[22] R. Mahara, C.Z. Harun, and N. Usman, "Gaya Kepemimpinan Kepala Sekolah Dalam Meningkatkan Kedisiplinan Guru Pada Man Pegasing Kebupaten Aceh Tengah," Jurnal Administrasi Pendidikan: Program Pascasarjana Unsyiah, vol. 5, no. 1, 2017. 